Vol. 24, No. 2, April 2021, hlm. 249-257

p-ISSN: 1410-9344; e-ISSN: 2549-5631

\title{
Optimalisasi Palang Merah Remaja dalam Pencegahan Penyakit Tidak Menular di Era Pandemi COVID-19
}

\author{
${ }^{1}$ Risalina Myrtha, ${ }^{2}$ Amelya Augusthina Ayusari, ${ }^{3}$ Ratna Kusumawati, ${ }^{4}$ Alamanda Murasmita, \\ ${ }^{5}$ Coana Sukmagautama, ${ }^{6}$ Adigama Priamas, ${ }^{7}$ Ainal Fadly \\ ${ }^{1,6,7}$ Program Studi Jantung dan Pembuluh Darah, Fakultas Kedokteran, Universitas Sebelas Maret \\ ${ }^{2,3}$ Program Studi Kedokteran, Fakultas Kedokteran, Universitas Sebelas Maret \\ ${ }^{4}$ Program Studi Ilmu Kesehatan Kulit dan Kelamin, Fakultas Kedokteran Universitas Sebelas Maret \\ ${ }^{5}$ Program Studi Profesi Dokter, Fakultas Kedokteran, Universitas Sebelas Maret \\ 1,4,5 Rumah Sakit Universitas Sebelas Maret \\ Email: ${ }^{1}$ risalinamustarsid@staff.uns.ac.id
}

\section{Article Info}

Submitted: 15 October 2020

Revised: 12 December 2020

Accepted: 26 December 2020

Published: 21 April 2021

Keywords: Non communicable disease, youth red cross
Kata kunci: PMR, Penyakit Tidak Menular

\begin{abstract}
Non Communicable Disease (NCD) is the leading cause of death worldwide and has become a huge social and economic burden. NCD is preventable if risk factors are controlled earlier. The contribution of youth to prevent NCD is sharing useful messages to family, schoolmates, and their environment. This online event was dedicated by graduates of this school. The participants were youth red cross members of Public Senior High School 1 of Surakarta. It is an active organization, but among its program, NCD has never been raised as an issue. There was lack of knowledge about NCD among its members. This school is one of the most favorite school in Surakarta. It becomes a role model and benchmark for others. This training was divided into NCD and new adaptation habits sessions. 34 youth red cross members of Public Senior High School 1 of Surakarta attended. There was a significant increase of postest score compared to pretest (10 vs $6.24 \pm 2.26, p<0.001$ ). $68 \%$ of participants totally agree that this training was interesting. 56\% of participants completely agreed that it was easily understood. $84 \%$ of participants totally agreed that it was relevant with recent condition. COVID-19 pandemic brings adaptation of new habits. One of which is practicing physical distancing, that can bring consequences of inadequate physical activity. If these conditions are not well-managed, this can grow new risk factors of NCD or even exacerbate pre-existing risk factors. We suggest an early risk factor screening among students.
\end{abstract}

\footnotetext{
Abstrak

Penyakit Tidak Menular (PTM) merupakan penyebab kematian terbesar di dunia yang memberikan beban sosial ekonomi yang berat. PTM merupakan penyakit yang dapat dicegah dengan mengendalikan
} 
faktor risiko sejak dini. Generasi muda dapat berkontribusi dalam pencegahan PTM dengan cara membagikan pesan-pesan bermanfaat tersebut ke lingkungan keluarga, sekolah, maupun masyarakat. Kegiatan ini merupakan kegiatan persembahan alumni untuk memberikan pelatihan pencegahan PTM yang dilakukan secara daring. Kegiatan ini diikuti oleh anggota PMR SMA Negeri 1 Surakarta. Organisasi ini merupakan organisasi yang cukup aktif, tetapi selama ini belum pernah mengangkat tema PTM dalam kegiatannya. Pengetahuan anggotanya tentang PTM masih kurang. SMA Negeri 1 Surakarta merupakan salah satu sekolah favorit di Surakarta dan menjadi percontohan dan tolak ukur prestasi bagi sekolah lainnya. Kegiatan ini dibagi 2 sesi yaitu pencegahan dan penatalaksanaan awal PTM dan adaptasi kebiasaan baru pada era tatanan baru. Pelatihan ini diikuti oleh 34 orang anggota PMR SMA Negeri 1 Surakarta. Didapatkan kenaikan signifikan rerata nilai postest (nilai rerata 10) dibandingkan pretest (nilai rerata 6,24 $\pm 2,26$; $(\mathrm{p}<0,001)$. 68\% peserta sangat setuju pelatihan ini menarik, $56 \%$ peserta sangat setuju bahwa materi pelatihan ini mudah dipahami, dan $84 \%$ peserta sangat setuju materi pelatihan ini relevan dengan kondisi saat ini. Pelatihan ini menambah pengetahuan tentang pencegahan PTM pada anggota PMR. Adanya pandemi COVID-19 menyebabkan adanya kebiasaan baru. Apabila tidak dikelola dengan baik, kondisi ini dapat menyebabkan timbulnya faktor risiko PTM atau memperburuk faktor risiko yang ada. Kami menyarankan dilakukannya skrining dini faktor risiko PTM pada semua siswa.

\section{PENDAHULUAN}

Menurut hasil Riset Kesehatan Dasar (Riskesdas) tahun 2018, prevalensi penyakit tidak menular mengalami peningkatan dari hasil Riskesdas tahun 2013. Penyakit tersebut antara lain kanker, strok, penyakit ginjal kronis, diabetes melitus, dan hipertensi. Selain itu, tingkat obesitas pada orang dewasa di Indonesia meningkat menjadi 21,8\% dibandingkan dengan hasil Riskesdas 2013 sebesar 14,8\%. Prevalensi obesitas sentral juga meningkat. Jika pada tahun 2013, prevalensi obesitas sentral sebesar $26,6 \%$, di tahun 2018, prevalensinya meningkat menjadi 31\%. Obesitas dapat meningkatkan risiko terjadinya gangguan kesehatan yang serius, seperti penyakit jantung, diabetes, dan hipertensi. Selain itu, obesitas juga dapat menyebabkan gangguan kualitas hidup dan masalah psikologi, seperti depresi (Badan Penelitian dan Pengembangan Kesehatan Kementerian Kesehatan, 2018).

World Health Organization (WHO) melaporkan bahwa penyakit tidak menular bertanggung jawab sebagai penyebab kematian pada 38 juta jiwa (68\%) dari total kematian 56 juta jiwa pada tahun 2012. Sebanyak 16 juta jiwa (lebih dari 40\%) merupakan kematian prematur pada usia di bawah 70 tahun. Hampir tiga perempat dari seluruh kematian karena penyakit tidak menular (28 juta) dan mayoritas kematian prematur (82\%) terjadi di negara ekonomi rendah dan menengah. Konsekuensi sosial dan ekonomi penyakit tidak menular dirasakan oleh semua negara, tetapi terutama sangat memberatkan pada populasi dengan ekonomi rendah, sehingga menurunkan beban global penyakit tidak menular menjadi prioritas dalam pembangunan yang berkelanjutan (World Health Organization, 2014).

Penyakit tidak menular merupakan salah satu tantangan kesehatan masyarakatyang paling berat di abad ke 21. Pengaruh sosial dan ekonomi dari penyakit tidak menular terus mengintai terhadap pembangunan berkelanjutan. Penyakit tidak menular merupakan penyebab kematian terbanyak. Empat kelompok utama penyakit 
tidak menular, yaitu penyakit kardiovaskuler, kanker, penyakit paru kronis, dan diabetes, merupakan penyebab $82 \%$ dari seluruh kematian di dunia. Pada tahun 2025, biaya ekonomi global dari keempat kelompok utama penyakit tidak menular tersebut diperkirakan akan melampaui 51 juta dolar Amerika (Baker et al., 2016). Di Jawa Tengah, jumlah kasus penyakit tidak menular menunjukkan angka yang meningkat dari tahun ke tahun. Demikian juga di Kota Surakarta, berdasarkan laporan dari Puskesmas dan Rumah Sakit, pada tahun 2014 terjadi peningkatan pada hampir semua jenis penyakit tidak menular dibandingkan dengan tahun sebelumnya (Dinas Kesehatan Kota Surakarta, 2014).

Salah satu jenis penyakit tidak menular terbanyak adalah hipertensi. Hipertensi menempati urutan teratas kasus penyakit tidak menular. Pada tahun 2018, Puskesmas melaporkan adanya 67.827 kasus hipertensi esensial. Begitu pula dengan Diabetes Melitus (DM), penyakit ini menempati 10 besar pola penyakit di Surakarta. Kasus DM yang dilaporkan pada tahun 2018 mencapai 16.852 kasus, meningkat jika dibandingkan tahun sebelumnya sebanyak 13.902 kasus. Penyakit tidak menular lainnya yang cukup banyak ditemukan adalah obesitas. Kasus obesitas yang dilaporkan pada tahun 2018 mencapai 7.646 kasus, meningkat bila dibandingkan dengan tahun sebelumnya sebanyak 6.395 kasus. Hal ini memerlukan perhatian dan penanganan yang baik dari semua pihak (Dinas Kesehatan Kota Surakarta, 2019).

Penyakit tidak menular sebetulnya merupakan penyakit yang dapat dicegah bila dikendalikan faktor risikonya. Pencegahan dan penanggulangan penyakit tidak menular merupakan salah satu usaha yang dapat dilakukan dengan melakukan deteksi dini faktor risiko. Dinas Kesehatan Kota Surakarta melakukan kebijakan ini dengan pendekatan berbasis masyarakat melalui Posbindu PTM (Pos Pembinaan Terpadu Penyakit Tidak Menular) (Dinas Kesehatan Kota Surakarta, 2014).

Cara pendekatan pencegahan yang efektif digunakan menurut WHO Global Action Plan adalah koordinasi multisektoral. Pendekatan lainnya yang penting dilakukan adalah melalui kemitraan dengan pemuda dan masyarakat sipil yang relevan (World Health Organization, 2013). Faktor-faktor risiko penyakit tidak menular dapat kita cegah dengan memberdayakan organisasi pemuda karena pada usia tersebut rentan mulai timbul faktor risiko penyakit tidak menular.

Bagi generasi muda, memahami penyakit tidak menular dan faktor risikonya merupakan hal yang sangat penting. Dua pertiga kematian prematur pada orang dewasa berhubungan dengan kondisi pada masa kanak-kanak atau berkaitan dengan kebiasaan-kebiasaan yang dimulai pada usia remaja. Kebiasaan-kebiasaan itu misalnya merokok dan berolahraga. Lebih dari 150 juta anak muda di dunia merokok, $81 \%$ remaja tidak melakukan olahraga yang cukup, $11,7 \%$ remaja mempunyai episode sering minum alkohol, dan 41 juta anak di bawah 5 tahun kelebihan berat badan atau mengalami obesitas. Kebiasaan dan lingkungan yang tidak sehat menyebabkan jumlah penyakit tidak menular yang tetap bahkan meningkat pada generasi yang akan datang (Hauerslev dan Allen, 2018).

Generasi muda saat ini bisa memperoleh informasi dengan mudah dan mempunyai kapasitas untuk menindaklanjuti informasi tersebut untuk membentuk kebiasaan pada kehidupannya sehingga dapat menentukan status kesehatannya sendiri. Generasi muda dapat berkontribusi dalam pencegahan penyakit tidak menular dengan beberapa cara. Dengan menggunakan media-media baru yang lebih modern, aspirasi yang disuarakan oleh generasi muda dapat memberikan perspektif baru dalam pencegahan dan pengendalian penyakit tidak menular dengan membagikan pesanpesan bermanfaat dalam hal faktor risiko dan intervensinya. Generasi muda dapat berbaur dengan berbagai komunitas dan membagikan informasi tentang penyakit tidak menular (Baker et al., 2016).

Pada kegiatan pengabdian masyarakat ini, pelatihan ditujukan pada generasi muda, dalam hal ini adalah anggota PMR. Edukasi mengenai pencegahan dan pengendalian PTM kepada masyarakat dengan menyasar masyarakat usia remaja dilakukan untuk pembiasaan pola hidup sehat sejak usia muda. Selain itu, remaja merupakan kelompok pengguna tertinggi media 
sosial dapat menjadi influencer edukasi tentang pencegahan PTM di media sosial. Anak-anak muda ini diharapkan dapat memulai pencegahan penyakit tidak menular sejak dini dengan mengendalikan faktor-faktor risiko penyakit tidak menular. Selain itu, sebagai anggota PMR, diharapkan anak-anak muda tersebut dapat membagi informasi tersebut ke lingkungannya baik di keluarga, sekolah, maupun di lingkungan tempat tinggalnya.

PMR SMA Negeri 1 Surakarta merupakan kegiatan ekstrakurikuler yang cukup aktif melakukan program kegiatannya. Akan tetapi, dari keseluruhan kegiatan yang dilakukan selama ini belum pernah mengangkat tema Penyakit Tidak Menular (PTM) (PMR Wira SMA Negeri 1 Surakarta, 2017), walaupun belum didapatkan data jumlah kejadian penyakit tidak menular dan faktor risikonya di SMA Negeri 1 Surakarta. SMA Negeri 1 Surakarta merupakan sekolah favorit di Surakarta dan termasuk 100 besar sekolah terbaik di Indonesia. SMA Negeri 1 Surakarta banyak mejadi percontohan dan tolak ukur prestasi bagi sekolah yang lain (Sushmita, 2019). Oleh karena itu, optimalisasi peran PMR di SMA Negeri 1 Surakarta sangat penting dalam pencegahan PTM di masyarakat terutama pada kelompok usia remaja dan menjadi percontohan bagi sekolah lain

\section{METODE PELAKSANAAN}

Pelatihan dilaksanakan secara daring dan diikuti oleh anggota PMR SMA Negeri 1 Surakarta dengan menggunakan aplikasi Microsoft Teams dengan susunan acara pelatihan sebagai berikut:

a. Pretest yang diberikan dan dikerjakan melalui aplikasi Google form. Pretest ini terdiri dari 10 pertanyaan pilihan ganda dan dikerjakan dalam waktu 10 menit.

b. Materi pertama dengan tema pencegahan dan penatalaksanaan awal penyakit tidak menular di masyarakat yang disampaikan oleh dr. Coana Sukmagautama, Sp.PD. Materi pertama ini mengacu pada Buku KIE Kader Kesehatan Remaja yang diterbitkan oleh Kementerian Kesehatan Republik Indonesia. Pada sesi ini disampaikan tentang pencegahan dan penatalaksanaan awal beberapa macam penyakit tidak menular yang paling banyak dimasyarakat.

c. Materi kedua dengan tema adaptasi kebiasaan baru di era tatanan baru pandemi COVID-19 yang disampaikan oleh dr. Alamanda Murasmita, Sp.DV. Pada sesi ini disampaikan tentang pentingnya kita menyaring informasi yang betul dan valid pada masa pandemi sehingga tidak menelan mentah-mentah berita yang diterima, bersikap bijak dalam menerima informasi tentang COVID-19, dan tidak menyebarkan berita hoaks.

d. Sesi diskusi dan tanya jawab

Pada sesi ini diberikan kesempatan untuk berdiskusi antara peserta dan narasumber. Sesi diskusi berlangsung dengan menarik. Beberapa pertanyaan aktual terkait dengan kondisi yang saat ini sedang dihadapi yaitu pandemi COVID-19 disampaikan oleh peserta. Beberapa peserta mengkonfirmasi informasi terkait COVID-19 yang beredar di masyarakat.

e. Postest dan pengisian kuesioner umpan balik.

Postest dan kuesioner umpan balik peserta diberikan dan dikerjakan secara daring melalui aplikasi Google form. Postest diberikan 10 pertanyaan pilihan ganda dan dikerjakan dalam waktu 10 menit, untuk mengevaluasi apakah ada peningkatan pengetahuan peserta dalam pencegahan penyakit tidak menular dan adaptasi kebiasaan baru. Kuesioner umpan balik diberikan untuk mengevaluasi pelaksanaan pelatihan ini.

Hasil nilai pretest dan postest disajikan pada Tabel 1 dan dihitung rerata masing-masing pretest dan postest. Perbedaan antara pretest dan postest dianalisis dengan menggunakan uji $\mathrm{t}$ berpasangan. Nilai $\mathrm{p}<0,05$ dianggap bermakna secara statistik. Analisis statistik dilakukan dengan menggunakan software IBM SPSS versi 22. Sedangkan hasil pengisian kuesioner umpan balik disajikan dalam bentuk grafik pada Gambar 1. Target kegiatan ini adalah peningkatan pengetahuan tentang penyakit tidak menular dengan luaran berupa modul singkat tentang pencegahan penyakit tidak menular. 

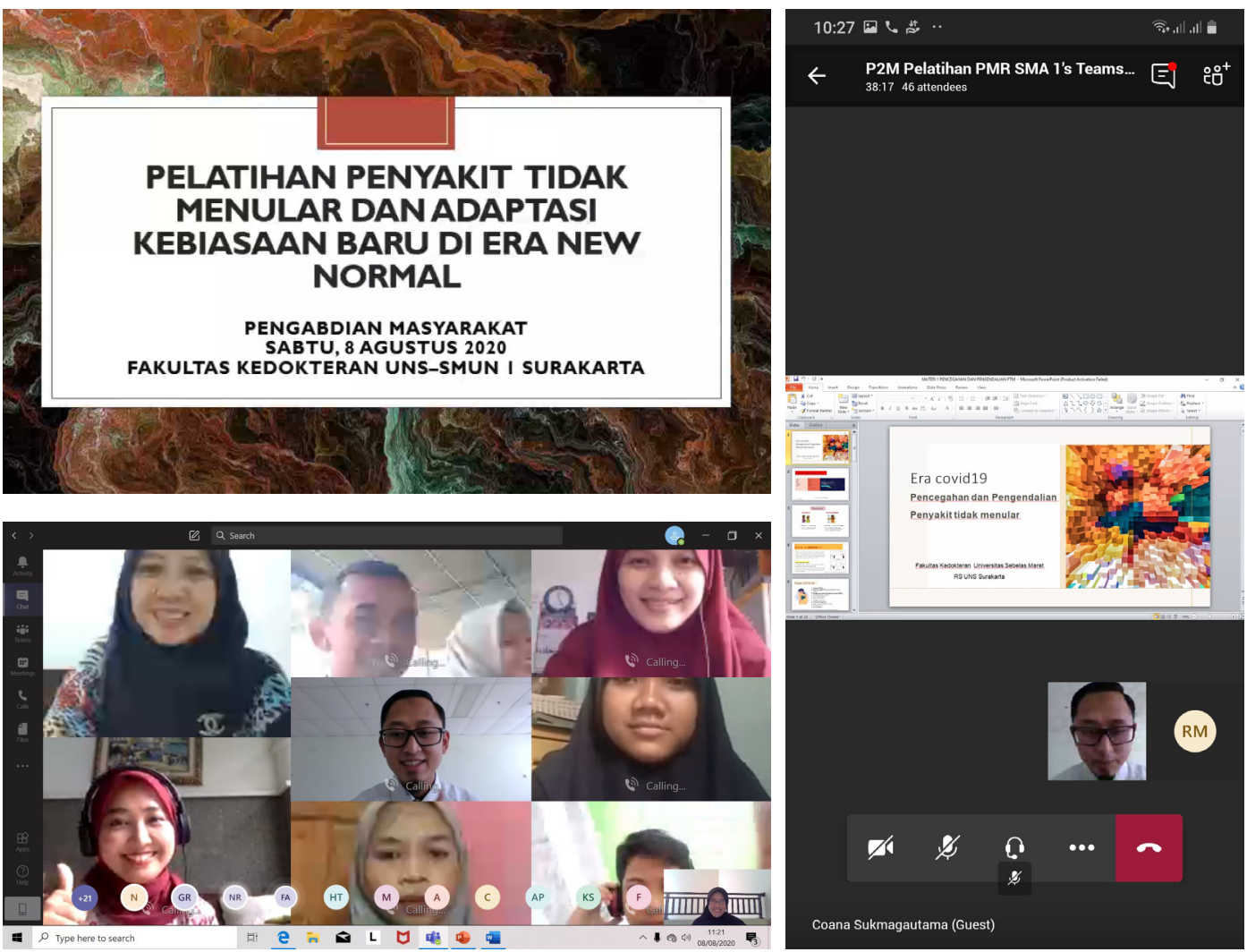

Gambar 1. Pelaksanaan Kegiatan Menggunakan Aplikasi Microsoft Teams

\section{HASIL DAN PEMBAHASAN}

Pelatihan dilaksanakan secara daring dan diikuti oleh 34 orang anggota PMR SMA Negeri 1 Surakarta, Pembina PMR SMA Negeri 1 Surakarta, dan perwakilan sekolah. Dari 34 orang peserta, hanya 25 orang peserta yang menjawab pretest dan postest secara lengkap. Sedangkan 8 orang peserta hanya menjawab pretest dan 1 orang hanya menjawab postest. Rerata nilai pretest adalah $6,24 \pm 2,26$, sedangkan rerata nilai postest adalah 10. Didapatkan kenaikan yang signifikan antara nilai pretest dan postest ( $\mathrm{p}<0,001)$. Hal ini menunjukkan bahwa target kegiatan ini berupa peningkatan pengetahuan tentang penyakit tidak menular dapat tercapai dengan baik dan sasaran pelatihan ini cukup tepat karena pengetahuan anggota PMR SMA Negeri 1 Surakarta tentang penyakit tidak menular masih kurang.

Dari kuesioner umpan balik peserta, didapatkan hasil $68 \%$ peserta sangat setuju bahwa pelatihan ini sangat menarik, sedangkan $32 \%$ sisanya setuju bahwa pelatihan ini menarik. $56 \%$ peserta sangat setuju bahwa materi pelatihan mudah dipahami, $40 \%$ peserta setuju bahwa materi mudah dipahami, sedangkan $4 \%$ (1 orang) peserta merasa bahwa materi pelatihan tidak mudah dipahami. 84\% peserta sangat setuju bahwa materi pelatihan ini relevan dengan kondisi saat ini, sedangkan 16\% sisanya setuju bahwa materi pelatihan ini relevan dengan kondisi saat ini.

Beberapa permasalahan yang dihadapi mitra terkait dengan pengendalian penyakit tidak menular adalah adanya peningkatan prevalensi penyakit tidak menular di Jawa Tengah, khususnya daerah Kota Surakarta yang terus meningkat dari tahun ke tahun. Selain itu, didapatkan adanya transisi epidemiologi dari penyakit menular menjadi penyakit tidak menular yang disebabkan oleh adanya perubahan perilaku dan gaya hidup masyarakat. Transisi perilaku masyarakat ini meliputi kurangnya aktivitas fisik, kurangnya konsumsi sayur atau serat, meningkatnya remaja yang mengkonsumsi tembakau atau rokok, dan meningkatnya konsumsi alkohol pada remaja. Selain itu, didapatkan adanya peningkatan angka kematian akibat penyakit tidak menular. Untuk mengatasi permasalahan tersebut, maka diadakan pelatihan pencegahan penyakit tidak menular pada remaja. Dengan pelatihan ini diharapkan generasi muda yang diwakili oleh 
anggota PMR dapat menerapkan gaya hidup sehat sehingga dapat menurunkan angka kejadian penyakit tidak menular di masa yang akan datang.

Tabel 1. Hasil Nilai Pretest dan Postest Peserta Pelatihan.

\begin{tabular}{ccc}
\hline Peserta & Nilai Pretest & Nilai Postest \\
\hline A & 4 & 10 \\
B & 6 & 10 \\
C & 10 & 10 \\
D & 8 & 10 \\
E & 6 & 10 \\
F & 10 & 10 \\
G & 6 & 10 \\
H & 6 & 10 \\
I & 10 & 10 \\
J & 4 & 10 \\
K & 6 & 10 \\
L & 6 & 10 \\
M & 8 & 10 \\
N & 4 & 10 \\
O & 6 & 10 \\
P & 6 & 10 \\
Q & 10 & 10 \\
R & 4 & 10 \\
S & 2 & 10 \\
T & 4 & 10 \\
U & 8 & 10 \\
V & 4 & 10 \\
W & 6 & 10 \\
X & 8 & 10 \\
Y & 4 & \\
\hline & & 10 \\
\hline
\end{tabular}

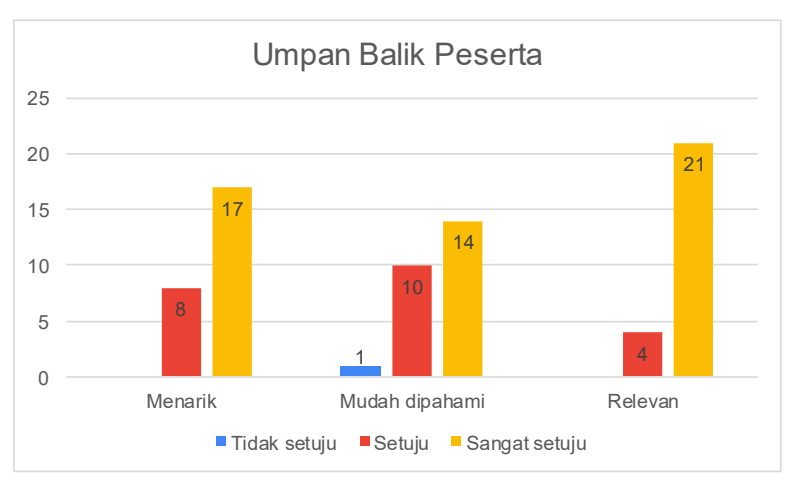

Gambar 2. Umpan Balik Peserta Pelatihan
Remaja merupakan fase kehidupan manusia yang cukup unik, di mana perubahan biologis dan psikososial terjadi dengan cepat dan mempengaruhi tiap aspek pengalaman hidup remaja tersebut dan meletakkan dasar untuk kehidupan nantinya. Otak remaja dapat berkembang dan beradaptasi dengan cepat, memberikan kemungkinan untuk meletakkan dasar-dasarkebiasaanhidupsehat,tetapipadasisi lain, memungkinkan adanya adaptasi kebiasaankebiasaan risiko tinggi. Pada kenyataannya, kebiasaan tersebut dianggap sebagai suatu hal yang normatif, dan bukan sebagai suatu hal yang patologis. Secara mengejutkan, konsumsi rokok dan alkohol seringkali dimulai pada usia remaja dan menyebabkan terjadinya kematian prematur karena penyakit tidak menular di kemudian hari (Hauerslev and Allen, 2018).

Kelebihan berat badan dan obesitas di Amerika menduduki angka paling tinggi dari seluruh dunia. Kurang lebih $21 \%$ remaja di Amerika mengalami kelebihan berat badan dan $6 \%$ mengalami obesitas. Pada waktu yang sama, remaja yang merokok juga semakin banyak dibandingkan dengan sebelumnya, tidak hanya pada remaja laki-laki, tetapi juga wanita. Di Amerika, 25\% remaja berusia 13-15 tahun merokok. Begitu juga dengan konsumsi alkohol, konsumsi alkohol banyak dimulai pada usia muda terutama pada negara-negara di benua Amerika yang berpendapatan rendah hingga sedang, dilaporkan 14\% remaja wanita dan 18\% remaja pria berusia 13-15 tahun mengkonsumsi alkohol. Pada masa remaja dan dewasa muda, orang-orang membuat pilihan yang akan mempengaruhi kehidupannya di masa yang akan datang, baik itu dalam hal status kesehatan di masa depan, biaya perawatan kesehatan, dan usaha untuk mendapatkan umur yang panjang. Pilihan-pilihan tersebut dibentuk oleh lingkungan sosial maupun fisik dan bagaimana gaya hidup, belajar, bermain, dan bekerja (Oliel et al., 2020).

Generasi muda telah membuktikan kemampuan mereka untuk menjadi bagian penting dalam penanggulangan penyakit tidak menular. Generasi muda memahami bahwa saat ini penyakit tidak menular sangatlah mengancam dan akan mempengaruhi generasi mereka di masa depan jika tidak dilakukan 
tindakan yang adekuat. Pada Maret 2017, International Federation of Medical Students' Association (IFMSA) dengan co-host dari WHO, mengungkapkan aksi jangka panjang yang dibutuhkan untuk perbaikan penanganan penyakit tidak menular melalui Budva Youth Declaration. Asosiasi mahasiswa kedokteran nasional berhubungan dengan kementerian masing-masing negara dan juga Dekan masingmasing Fakultas Kedokteran untuk melakukan advokasi kebijakan penyakit tidak menular dari tingkat lokal hingga global. Selain itu, generasi muda merupakan generasi yang secara signifikan terdampak oleh penyakit tidak menular, dan nantinya mereka akan menjadi suatu generasi yang dibentuk oleh keputusan yang dibuat pada saat ini (Hauerslev dan Allen, 2018). Potensi dari pencegahan primer penyakit tidak menular untuk mengurangi beban sosial dan ekonomis karena dilaksanakan sedini mungkin. Generasi muda memberikan kesempatan yang sangat baik untuk dilakukannya pencegahan primer penyakit tidak menular (Bay et al., 2017).

Adanya kemunculan tiba-tiba COVID-19, yangmerupakan penyakitmenular, menyebabkan adanya perubahan konsep kesehatan dan penyakit. Kita semua diingatkan bahwa penyakit menular ternyata dapat menyebabkan ancaman serius terhadap semua aspek kehidupan, meliputi kesehatan, ekonomi, pendidikan, dan hubungan antar manusia. Selain itu, kita juga diharuskan mengubah konsep hidup normal menjadi "Normal Baru". Telah diprediksi bahwa adanya pandemi COVID-19 akan menyebabkan terjadinya pandemi lain, yaitu pandemi penyakit tidak menular. Hal ini menyadarkan kita adanya konvergensi tanpa batas antara penyakit menular dan penyakit tidak menular (Shibata et al., 2020).

Pengaruh COVID-19 terhadap penyakit tidak menular ada beraneka macam. Adanya physical distancing atau karantina dapat memperburuk penatalaksanaan faktor risiko penyakit tidak menular, misalnya diet yang tidak sehat, aktivitas fisik, rokok, dan konsumsi alkohol. Adanya penerapan aktivitas dari rumah menyebabkan terjadinya penurunan aktivitas fisik dan peningkatan beban kesehatan mental, yang dapat menyebabkan peningkatan konsumsi makanan tidak sehat, peningkatan konsumsi rokok, dan alkohol. Selain itu, tanpa adanya penatalaksanaan yang baik, kondisi pandemi dapat memperburuk kondisi penyakit kronis karena situasi yang penuh tekanan akibat keterbatasan aktivitas fisik, situasi ekonomi yang tidak menentu, dan perubahan pada kebiasaan normal. Pencegahan penyakit tidak menular selama masa pandemi ini sangat penting mengingat adanya kemungkinan penderita penyakit kronis yang asimptomatik atau belum terdeteksi seperti kasus-kasus hipertensi dan DM yang seringkali belum terdiagnosis (Kluge et al., 2020).

Pencegahan penyakit tidak menular selama pandemi ini sangatlah penting karena penyakit tidak menular merupakan faktor risiko mayor untuk pasien COVID-19. Di Italia, mayoritas pasien di rumah sakit yang meninggal karena COVID-19 mempunyai komorbid $(96,2 \%)$, terutama komorbid penyakit tidak menular, yang paling sering adalah hipertensi $(69,2 \%)$, DM $(31,8 \%)$, penyakit jantung iskemik (28,2\%), penyakit paru obstruktif kronis $(16,9 \%)$, dan kanker $(16,3 \%)$. Tetapi banyak pula kematian karena COVID-19 terjadi pada pasien usia lanjut yang mempunyai komorbiditas (Kluge et al., 2020). Seseorang yang mempunyai faktor risiko akan mengalami kondisi yang lebih berat jika terinfeksi COVID-19. Sebagai contoh, merokok berhubungan dengan derajat keparahan COVID-19 yang lebih berat. Rokok dan segala bentuk lain penggunaan tembakau seperti pipa rokok, e-cigarette dapat meningkatkan risiko terinfeksi COVID-19 melalui kontak tangan dan mulut. Faktor risiko lainnya yang seringkali timbul karena kurangnya aktivitas fisik adalah kelebihan berat badan dan obesitas. Kelebihan berat badan dan obesitas merupakan komorbid paling yang paling sering didapatkan pada pasien COVID-19 yang mengalami hospitalisasi dan berkaitan dengan risiko yang lebih tinggi mengalami kejadian tambahan. Obesitas dianggap sebagai kondisi pro inflamasi yang mengganggu respon imun terhadap infeksi virus, menginduksi terjadinya DM dan stres oksidatif, serta membatasi fungsi kardiovaskular maupun sistem respirasi. (WHO dan UNDP, 2020).

Selain itu, selama terjadinya pandemi COVID-19, pasien dengan penyakit kronis yang membutuhkan pengobatan jangka panjang 
seringkali mengalami kesulitan untuk bisa menjangkau layanan kesehatan. Masalah ini menjadi semakin serius pada daerah yang terpencil karena adanya pembatasan transportasi publik dan penerapan lockdown menyebabkan terbatasnya akses terhadap layanan kesehatan. Penanganan COVID-19 masih menjadi prioritas utama saat ini, sehingga kasus-kasus non emergensi menjadi tertunda penanganannya. Karena pasien dengan usia lanjut dan penyakit kronis mempunyai risiko lebih tinggi untuk menderita COVID-19 yang lebih parah dan seringkali disertai dengan komplikasi yang berat, sehingga penderita penyakit kronis dan usia lanjut dianjurkan untuk tinggal di rumah. Tetapi di sisi lain, hal ini mempunyai akibat buruk yaitu berkurangnya aktivitas fisik karena berkurangnya mobilitas. Selain itu, COVID-19 juga berpengaruh terhadap kondisi psikologis karena menyebabkan rasa takut (Anthonius et al., 2020). Durasi periode lockdown berbanding lurus dengan kondisi gula darah yang tidak terkontrol dan terjadinya komplikasi DM, yang kemudian selanjutnya menyebabkan penambahan beban bagi sistem layanan kesehatan (Nachimuthu et al., 2020).

\section{SIMPULAN}

Pelatihan pencegahan penyakit tidak menular yang dilaksanakan secara daring kepada anggota PMR SMA Negeri 1 Surakarta ini bermanfaat dalam meningkatkan pengetahuan anggota PMR SMA Negeri 1 Surakarta dalam hal pencegahan penyakit tidak menular dan adaptasi kebiasaan baru di era pandemi COVID-19. Generasi muda dapat berkontribusi besar dalam pencegahan penyakit tidak menular karena banyak faktor risiko penyakit tidak menular dan kebiasaan-kebiasaan kurang sehat yang dimulai pada usia remaja. Selain itu, generasi muda diharapkan dapat membagikan informasi ke lingkungan keluarga, sekolah, maupun masyarakat. Generasi muda juga telah terbukti memberikan kontribusi besar ke negara dengan melakukan advokasi kebijakan pencegahan penyakit tidak menular. Di era tatanan normal baru ini, terjadi adaptasi-adaptasi kebiasaan baru seperti adanya physical distancing, yang diikuti adanya kebijakan bekerja atau belajar dari rumah, sehingga seringkali menyebabkan adanya perburuk atau timbulnya faktor risiko baru karena kurangnya aktivitas fisik. Walaupun menerapkan kebiasaan-kebiasaan baru tersebut, diharapkan kebiasaan-kebiasaan sehat tetap dijaga dengan baik. Saran terkait dengan kegiatan pengabdian ini adalah dapat menerapkan pengetahuan ini untuk kegiatan skrining faktor risiko penyakit tidak menular pada siswa-siswi SMA, misalnya obesitas dan kebiasaan merokok, supaya sedini mungkin dapat mencegah terjadinya penyakit tidak menular di kemudian hari.

\section{PERSANTUNAN}

Penulis mengucapkan terima kasih kepada Ibu Dra. Harminingsih, M.Pd. Kepala SMA Negeri 1 Surakarta yang telah mendukung dan memberikan izin untuk pelaksanaan pelatihan ini. Penulis juga mengucapkan terima kasih kepada Bapak Barly Shodiq, Pembina PMR SMA Negeri 1 Surakarta yang telah mendukung terselenggaranya acara pengabdian masyarakat ini.

\section{REFERENSI}

Anthonius M, Huang I, Yonas E, et al. (2020) A Wave of Non-Communicable Diseases Following the COVID-19 Pandemic. Diabetes \& Metabolic Syndrome: Clinical Research \& Reviews 14: 979-980.

Badan Penelitian dan Pengembangan Kesehatan Kementerian Kesehatan (2018) Hasil Utama Riskesdas 2018. Available at: https://www.kemkes.go.id/resources/download/info-terkini/ hasil-riskesdas-2018.pdf.

Baker R, Taylor E, Essafi S, et al. (2016) Engaging Young People in The Prevention of Noncommunicable Diseases. Bull World Health Organ 2016;94:484 94: 484.

Bay JL, Hipkins R, Siddiqi K, et al. (2017) School-based Primary NCD Risk Reduction : Education and Public Health Perspectives. Health Promotion International 32: 369-379. 
Dinas Kesehatan Kota Surakarta (2014) Profil Kesehatan Kota Surakarta Tahun 2014. Surakarta. Available at: https://dinkes.surakarta.go.id/profil-kesehatan/.

Dinas Kesehatan Kota Surakarta (2019) Profil Kesehatan Kota Surakarta Tahun 2018. Available at: https://dinkes.surakarta.go.id/profil-kesehatan/.

Hauerslev M and Allen L (2018) Young People and Noncommunicable diseases - Vulnerable to Disease, Vital for Change. International Journal of Noncommunicable Diseases 3(2): 45-48.

Kluge HHP, Wickramasinghe K, Holly L Rippin RM, et al. (2020) Prevention and Control of NonCommunicable Diseases in The COVID-19 Response. Lancet 395: 1678-1680.

Nachimuthu S, Vijayalakshmi R, Sudha M, et al. (2020) Coping With Diabetes During the COVID-19 Lockdown in India : Results of An Online Pilot Survey. Diabetes \& Metabolic Syndrome: Clinical Research \& Reviews 14(4). Elsevier Ltd: 579-582. Available at: https://doi.org/10.1016/j. dsx.2020.04.053.

Oliel S, Baldwin A and Linn L (2020) Preventing Non-Communicable Diseases in Adolescents and Young Adults. Available at: https://www.paho.org/hq/index.php?option=com_content\&v iew $=$ article\&id=6680:2012-preventing-non-communicable-diseases-adolescents-youngadults\&Itemid=135\&lang=en (accessed 14 October 2020).

PMR Wira SMA Negeri 1 Surakarta (2017) Tentang PMR. Available at: http://pmrsmansaska.blogspot. com/p/tentang-pmr.html (accessed 11 December 2020).

Shibata S, Arima H, Asayama K, et al. (2020) Hypertension and Related Diseases in The Era of COVID-19: a Report From The Japanese Society of Hypertension Task Force on COVID-19. Hypertension Research. Springer US: 1028-1046. DOI: 10.1038/s41440-020-0515-0.

Sushmita CI (2019) Selamat! 4 SMA Soloraya Masuk 100 SMA Terbaik Indonesia. Available at: https:// www.solopos.com/selamat-4-sma-soloraya-masuk-100-sma-terbaik-indonesia-999981 (accessed 11 December 2020).

WHO and UNDP (2020) Responding to Non-Communicable Diseases During and Beyond the COVID-19 Pandemic. Available at: https://apps.who.int/iris/rest/bitstreams/1299982/retrieve.

World Health Organization (2013) Global Action Plan for the Prevention and Control of Noncommunicable Diseases 2013-2020. Geneva.

World Health Organization (2014) Global Status Report on noncommunicable disease 2014. Geneva. 